\title{
Effect of Honey Supplementation on Sperm Abnormality in Sperm Preservation of Brek Fish Systomous orphoides
}

\author{
Sri Widiyanti Rahayu Hilia ${ }^{1 *}$ Abinawanto ${ }^{1}$ Anang Hari Kristanto ${ }^{2}$ \\ ${ }^{1}$ Dept. of Biology, Faculty of Mathematics and Science (FMIPA), Universitas Indonesia, Depok, Indonesia \\ ${ }^{2}$ Research Institute for Freshwater Aquaculture and Fisheries Extension, Ministry of Marine Affairs West Java, \\ Indonesia \\ *Corresponding author. Email: abinawanto.ms@sci.ui.ac.id
}

\begin{abstract}
Honey is consisting of simple sugar, such as glucose, sucrose, and fructose, that could serve as a source of nutrition for sperm cells during preservation. The purpose of the study was to assess the effect of honey supplementation in the extender on the spermatozoa abnormality of brek fish Systomus orphoides (Valenciennes, 1842) $48 \mathrm{~h}$ after preserved at $4{ }^{\circ} \mathrm{C}$. The brek fish semen was obtained using the hand stripping method, and the diluent used is a mixture of fish ringers, $10 \%$ Methanol, and different concentrations of Honey solution $(5 \%$; $10 \%$; $15 \%$; and $20 \%$ ). Furthermore, equilibration was carried out at $28{ }^{\circ} \mathrm{C}$ for 1 minutes, and the sperm storage was carried out at $4{ }^{\circ} \mathrm{C}$ for $48 \mathrm{~h}$. The evaluation of semen was carried out macroscopically (color, volume, and $\mathrm{pH}$ ) and microscopically (abnormalities). The results of the ANOVA test followed by the Tukey test was significantly different $(\mathrm{p}<0.05)$ in the abnormality. The results showed that treatment of $5 \%$ honey solution was the optimum concentration because the lowest abnormality was $(11.85 \pm 0.45 \%)$.
\end{abstract}

Keywords: Sperm abnormality, honey, short-term preservation, Systomus orphoides

\section{INTRODUCTION}

Indonesia has a high diversity of freshwater fish. Based on Kottelat \& Whitten [1] there are more than 1300 species of freshwater fish in Indonesia. One of those species is red eye fish or usually known as brek fish (Systomus orphoides) [2]. Brek fish is belong to the Cyprinidae Family, which is distributed in Kalimantan, Sumatra and Java [3]. The enormous population growth has declined due to habitat destruction and overfishing. Fish breeding program for cultivation of brek fish is necessary. The success of the sperm-demanding fish spawning program starts by a high-quality sperm source, as well as its adequate collection, handling and storage. Therefore, the quality of semen should be increased [4]

Fish produce spermatozoa which are very viscous and, in some cases, only small amounts are produced [5]. Therefore, extender is needed for the spermatozoa dilution. Extender is a medium contains balanced salt solution that prevents activation of spermatozoa when diluted, it may be used as a diluent for the largest amount of sperm sample diluted for artificial reproduction [6]. The extender can extend the storage of fresh semen, protecting sperm against chemical and physical changes or contamination in their environment. [6]. In addition, it can be used to maximize the number of sperm needed to fertilize an egg while maintaining a given volume during the artificial reproduction process $[4,7]$.

Several researches have been published on the use of extender for improvement quality of fish sperm [4,5,6\&7]. Moreover, supplementation into extender is important to provide nutrient for preserved spermatozoa.

Honey contains of simple sugars such as fructose and glucose, amino acids, organic acids, enzymes, polyphenols, vitamins and minerals [8]. Honey also has bioactive constituents that play a role in antioxidant, anti-toxic, anti-mutagen, and antimicrobial processes in living cells [8]. Supplementation of honey into the extender has been reported by Ayer et al. [9] that used honey for 
diluting nile tilapia sperm. Honey has an important component to support the quality of sperm. Accordingly, the purpose of the study was to evaluate the effect of supplementation of various concentrations of honey in the extender on sperm abnormality of brek fish $S$. orphoides spermatozoa after $48 \mathrm{~h}$ preservation.

\section{MATERLIAL AND METHODS}

\subsection{Semen Collection}

The experiment was carried out from August through September 2020, at the Installations for Freshwater Fish Genetic Resources, Research Institute for Freshwater Aquaculture and Fisheries Extension, Ministry of Marine Affairs and Fisheries, Cijeruk, West Java, Indonesia.

Semen samples were obtaining from male brek fish by abdominal gently stripped method [5]. Prior to semen collection, the abdominal of brek fish was thoroughly washed to remove urine and other materials to prevent semen contamination during collection. Semen collected using needless syringe than place in 2-mL microtube vials (Nalgene and Nunc International). Immediately, after semen sampling was kept in cooler box. Standard analysis of seminal fluids involving macroscopy and microscopy was performed. Macroscopic parameters such as volume, $\mathrm{pH}$ and color were observed, while the observed microscopic parameter was abnormality. The extender was composed by fish Ringer, methanol $10 \%$ and was supplemented with honey $[0 \%, 5 \%$, $10 \%, 15 \%$, and $20 \%$ ] with different concentrations according to Putri et al. [10]. The extender for the control group was the $0 \%$ honey.

\subsection{Solution Preparation}

The extender solution that used was fish Ringer. The fish Ringer formulated by $3.25 \mathrm{~g} \mathrm{NaCl}, 0.175 \mathrm{~g}$ $\mathrm{CaCl}_{2 \cdot 2} \mathrm{H}_{2} \mathrm{O}, 0.125 \mathrm{~g} \mathrm{KCl}$, and $0.1 \mathrm{~g} \mathrm{NaHCO}_{3}$ diluted with distilled water until $500 \mathrm{~mL}$, then kept at $4{ }^{\circ} \mathrm{C}$ until 2 days [11]. Preparation of the $0,15 \mathrm{M}$ pH 6,8 phosphate buffer solution by diluted 5,34 $\mathrm{g}$ of $\mathrm{Na} 2 \mathrm{HPO} 4,2 \mathrm{H} 2 \mathrm{O}$ with distilled water until $200 \mathrm{~mL}$, and diluted $4.08 \mathrm{~g} \mathrm{KH}_{2} \mathrm{PO}_{4}$ in distilled water until $200 \mathrm{~mL}$. After that, mixing $\mathrm{Na}_{2} \mathrm{HPO}_{4 \cdot 2} \mathrm{H}_{2} \mathrm{O}$ solution with $\mathrm{KH}_{2} \mathrm{PO}_{4}$ solution, balancing the solution using $\mathrm{NaOH}$ until $\mathrm{pH}$ reach 6.8 , kept at $4^{\circ} \mathrm{C}$. Giemsa solution was formulated with dilute stock solution of Giemsa and a pH 6.8 phosphate buffer solution (1 Giemsa stock :10 phosphate buffer), Whatman filter paper number 1 used to filter buffer mixed solution [12].

\subsection{Semen Preservation}

Before preservation semen was diluted in the mixture solution. The mixture contains fish Finger solution, $10 \%$ methanol, and the honey solution $[0 \%$, $15 \% 10 \%$, and 20\%] as seen in Table 1 . The ratio between fresh semen and extender dilution was 1:10 [10]. The vials were labeled than preservation carried out by stored the vials at $4{ }^{\circ} \mathrm{C}$ up to 48 hours.

Table 1. Composition of experimental group

\begin{tabular}{lccccc}
\hline & \multicolumn{5}{c}{ Honey Concentrations } \\
\multicolumn{1}{l}{ Composition } & $\mathbf{0 \% \mathbf { H }}$ & $\mathbf{5 \% \mathbf { H }}$ & $\mathbf{1 0 \% \mathbf { H }}$ & $\mathbf{1 5 \% \mathbf { H }}$ & $\mathbf{2 0 \% \mathbf { H }}$ \\
\hline $\begin{array}{l}\text { Semen/Sperm } \\
(\mu \mathrm{L})\end{array}$ & 50 & 50 & 50 & 50 & 50 \\
$\begin{array}{l}10 \% \\
\text { Methanol } \\
(\mu \mathrm{L})\end{array}$ & 50 & 50 & 50 & 50 & 50 \\
$\begin{array}{l}\text { Fish Ringer } \\
\text { solution }(\mu \mathrm{L})\end{array}$ & 450 & 425 & 400 & 375 & 350 \\
$\begin{array}{l}\text { Honey/ H } \\
(\mu \mathrm{L})\end{array}$ & 0 & 25 & 50 & 75 & 100 \\
& & & & & \\
\end{tabular}

$* 0 \% \mathrm{H}, 5 \% \mathrm{H}, 10 \% \mathrm{H}, 15 \% \mathrm{H}, 20 \% \mathrm{H}=$ treatment group.

\subsection{Assessment of Sperm Abnormality}

Fresh semen volume was measured by scaled vial, semen color was observed by visual, and $\mathrm{pH}$ paper ( $\mathrm{pH}$ range 1-14) was used for measured fresh semen $\mathrm{pH}$. The smear preparation was used to determine sperm abnormality. Ten $\mu \mathrm{L}$ semen dropped above slide glass, spread the drop semen using another slide glass. The slide was dry, then fixed by $10 \%$ methanol for 3 minutes. Next, the slide was stained using 20\% Giemsa solution and was rinsed with aquadest to remove excess dye [13]. The abnormality of sperm was observed using microscope with magnification $10 \times 40$. Sperm abnormalities were assessed depending on the morphology of the head (swelling or shrinking) and the performance of the flagella (presence, absence or rupture). The percentage of abnormalities was detected using an optical microscope (Boeco BM-180 SP, Germany) linked to the digital eyepiece camera (MDCE 5 $5^{\mathrm{a}}$ operate with imaging analysis software (Scopephoto 2.0.4). 


\subsection{Statistical Analysis}

Abnormality data were analyzed by Analysis of Variance (ANOVA), that followed by Tukey Test with significance value level of 0.05 . SPSS version 23 for Windows was using as statistic program.

\section{RESULT AND DISCUSSION}

Fresh semen's appear milk-white with $\mathrm{pH} 8$ (Table 2.). Brek fish had $2 \mu \mathrm{m}$ rounded head spermatozoa, mid-piece, a flagellum 14-16 $\mu \mathrm{m}$, and lack of acrosome. The percentages of fresh spermatozoa abnormality shown in Table 2.

Table 2. Fresh spermatozoa characteristics

\begin{tabular}{clcc}
\hline \multicolumn{2}{c}{ Visible characteristics } & $\begin{array}{c}\text { Microscopic } \\
\text { Analysis }\end{array}$ \\
\hline $\begin{array}{c}\text { Volume } \\
(\mathrm{ml})\end{array}$ & Color & $\mathrm{pH}$ & $\begin{array}{c}\text { Abnormality } \\
(\%)\end{array}$ \\
$0.4 \mathrm{~mL}^{*}$ & $\begin{array}{l}\text { Milky } \\
\text { White }\end{array}$ & 8 & $10.16 \pm 1.39$ \\
\hline
\end{tabular}

\section{*replicates from 11 male fish}

The percentages of abnormality of brek fish spermatozoa after $48 \mathrm{~h}$ preservation at $4{ }^{\circ} \mathrm{C}$ were shown in Figure 1. The result showed that after preservation $48 \mathrm{~h}$, sperm abnormality increased significantly $(\mathrm{P}<0.05)$. The lowest rate spermatozoa abnormality after preservation was found in treatment $5 \%$ honey $(11.85 \pm 0.45 \%)$ and the highest rate abnormality in treatment $20 \%$ honey $(40.88 \pm 1.32 \%)$. Based on ANOVA test than followed by Tukey test result showed the significant different $(p<0.05)$ among control $0 \%$ and all treatment to the percentage of abnormality spermatozoa of brek fish, $48 \mathrm{~h}$ after preservation.

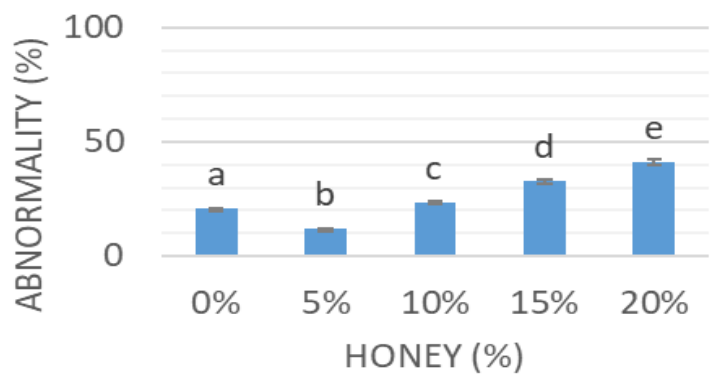

Figure 1. Spermatozoa abnormality of brek fish $48 \mathrm{~h}$ after preservation

Note: Different letters (a, b, c, d, e) in the bars showed significantly different among groups. significance level $\mathrm{P}<0.05$.

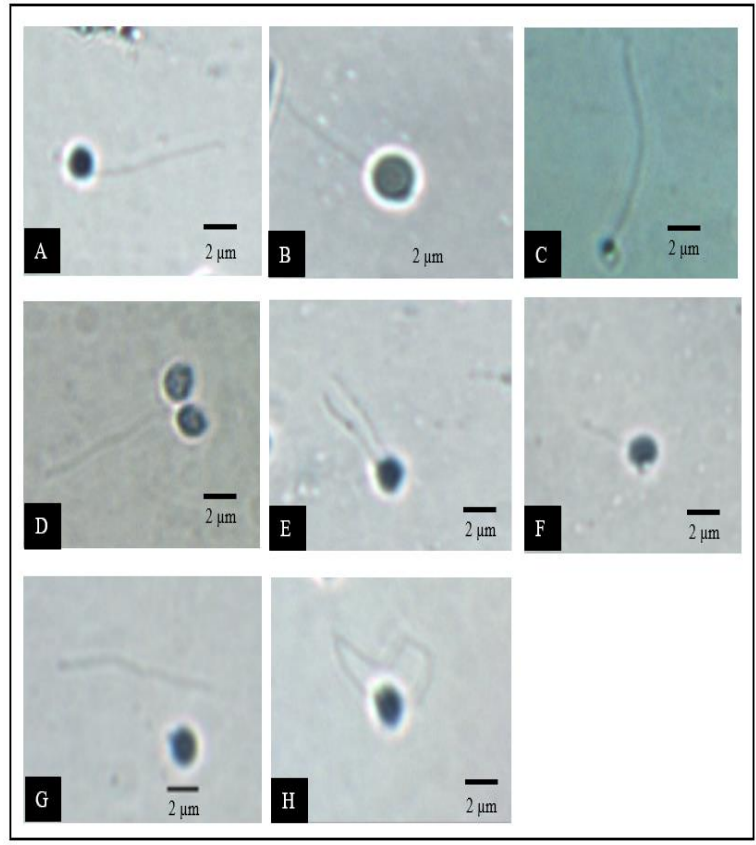

Figure 2. Brek fish spermatozoa. Normal spermatozoa (A); Macrocephalus (B); Microcephalus (C); Double head (D); Double tail (E); Small tail (F); Cut tail spermatozoa $(\mathrm{G})$; Bent tail $(\mathrm{H}) \mathrm{Bar}=2 \mu \mathrm{m}$.

As a result, treatment with $5 \%$ honey exhibited the lowest average abnormality percentage $(11.85 \pm 0.45 \%)$ and significantly different based on a significance level of 0.05 with a concentration of 10 , $15 \%$, and $20 \%$ (Figure 1). The spermatozoa consist of head, mid-piece and flagellum (Figure 2. A). Sperm head size is relatively small $(2-4 \mu \mathrm{m})$ when compared to total sperm size. Besides that, the size of head spermatozoa of brek fish $2 \mu \mathrm{m}$ similar to head sperm Cyprinus carpio head sperm 2-2.8 $\mu \mathrm{m}$ [14].

Furthermore, there were numerous variances of abnormal head in spermatozoa such as spermatozoa with macrocephalus, microcephalus, and two head (Figure 2. B, C, and D). Abnormal also found in the sperm flagellum (tail) that shown in Figure 2. E, F, G, and $\mathrm{H}$. According to Cruea [14], these abnormalities were arbitrarily classified as primary or secondary. Primary abnormalities included: 1) all head abnormalities including immature cells, 2) double tails, and 3) proximal protoplasmic droplets, those which are in contact with the head. Secondary abnormalities. Included: 1) distal or free-floating protoplasmic droplets, 2) reverse or bent tails, and 3) tailless heads. These abnormalities occur naturally. In contrary, the process of fertilization can inhibit by sperm with a high level of abnormality, because the abnormal spermatozoa caused imperfect movement so that the fertilization rate becomes low [13]. 
Extender fish Ringer solution that supplemented with $5 \%$ honey and $10 \%$ methanol gave the lowest results on abnormality spermatozoa of brek fish $S$. orphoides $48 \mathrm{~h}$ after preservation. Our results agreement with Putri et al. [10]. The content of honey has almost the same properties and characteristics in spermatozoa, including glucose and fructose which can be used as a source of energy to sustain life. Depending on Bogdanov, et al. [8] honey contains of simple sugars such as fructose and glucose. In turn, these sugars provide a substrate with sufficient additional energy for spermatozoa to withstand the low temperature and preservation period [15].

The percentage abnormality of spermatozoa increased gradually at higher concentration of honey above 5\%. This might be due to when honey concentration increased, it may lead to the increasing viscosity of diluent. However, honey supplementation in the extender should be used at the optimal concentration.

\section{CONCLUSION}

On the basis of the results, the conclusion is that the combination of $10 \%$ Methanol and the extender supplemented with 5\% honey showed the lowest spermatozoa abnormality $(11,85 \pm 0,45)$ rate of brek fish, $S$. orphoides after $48 \mathrm{~h}$ preservation.

\section{ACKNOWLEDGMENTS}

This research was supported by Direktorat Riset dan Pengabdian Masyarakat, Universitas Indonesia (Hibah PUTI 2020 with contract number NKB935/UN2.RST/HKP.05.00/2020) on behalf of Dr. Abinawanto and grateful to Dr. Anang Hari Kristanto as adviser. Thankful to all technical staff of Installations for Freshwater Fish Genetic Resources, Cijeruk, Bogor for every single support.

\section{REFERENCES}

[1] M. Kottelat, T. Whitten, Freshwater biodiversity in Asia: with special reference to fish, The World Bank, 1996.

[2] M. Suryaningsih, Sagi, K.H. Nitimulyo, S. Hadisusanto, Korelasi antara beberapa karakter reproduksi dengan panjang total ikan Brek [Puntius orphoides (Valenciennes 1842)] di Sungai Klawing Purbalingga, Majalah Ilmiah Biologi BIOSFERA: A Scientific Journal 8(3) (2011) 124-133. [In Bahasa Indonesia]

[3] E.M. Aljawad, M.S. Widodo, M. Fadjar, Digestive enzymes activities of brek (Puntius orphoides) fish based on fish development phase, International Journal of Scientific \& Technology Research 8(10) (2019) 2033-2035.

[4] F.A. Chapman, A semen extender for the shortterm storage of fish sperm, Fisheries and Aquatic Sciences, UF/IFAS Extension, 2018.

[5] Z.A. Muchlisin, M.N. Siti-Azizah, Preliminary study on the natural extenders for artificial breeding of African Catfish Clarias gariepinus (Burchell, 1822), AACL Bioflux 3(2) (2010) 119-124.

[6] C. Park, F.A. Chapman, An extender solution for the short-term storage of sturgeon semen, North American Journal of Aquaculture 67(1) (2005) 52-57. DOI: https://doi.org/10.1577/FA03-068.1

[7] Z.A. Muchlisin, Current status of extenders and cryoprotectants on fish spermatozoa cryopreservation. Biodiversitas Journal of Biological Diversity 6(1) 2005 66-69. DOI: https://doi.org/10.13057/biodiv/d060114

[8] S. Bogdanov, T. Jurendic, R. Sieber, P. Gallmann, Honey for nutrition and health: a review, Journal of the American College of Nutrition 27(6) (2008) 677-689. DOI: https://doi.org/10.1080/07315724.2008.10 $\underline{719745}$

[9] Y. Ayer, J. Mudeng, H. Sinjal, Daya tetas telur dan sintasan larva dari hasil penambahan madu pada bahan pengencer sperma ikan Nila (Oreochromis niloticus), e-Journal Budidaya Perairan 3(1) (2019). DOI: https://doi.org/10.35800/bdp.3.1.2015.695 0. [In Bahasa Indonesia]

[10] B.S.D. Putri, O.Z. Arifin, A.H. Kristanto, Honey effect on sperm motility of kancra fish (Tor soro Valenciennes, 1842) after 48 hours freezing, IOP Conference Series: Earth and Environmental Science, 2020, 441(1): 012062. DOI: $\quad$ https://doi.org/10.1088/1755$\underline{1315 / 441 / 1 / 012062}$

[11] Abinawanto, A.A. Pratiwi, R. Lestari, Sperm motility of giant gourami (Osphronemus goramy, Lacepede, 1801) at several concentrations of honey combined with DMSO after short-term storage, Aquacultre, Aquarium, Conservation \& Legislation Bioflux 10(2) (2017) 156-163. 
[12] WHO (World Health Organization), WHO laboratory manual for the examination and processing of human semen and cervical mucussemen interaction, Faculty of Medicine Universitas Indonesia Press, Jakarta, 1988, p.78.

[13] Abinawanto, S. Yimastria, P. Pertiwi, Sperm analysis of Lukas fish (Puntius bramoides): motility, viability and abnormalities,In: AIP Conference Proceedings, 2018, 2023(1): 020133.

[14] D.D. Cruea, Some chemical and physical characteristics of fish sperm, Transactions of the American Fisheries Society 98(4) (1969) 78578. https://doi.org/10.1577/15488659(1969)98[785:SCAPCO 2.0.CO;2

[15] R. Jerez-Ebensperger, L. Gil, N. Gonzalez, I. De Blas, The combined use of honey, garlic (allium sativum L.) and skimmed milk as an extender for chilling sheep semen, CryoLetters 36(4) (2015) 243-251. PMID: 26575999. 